\title{
Managing the monetary and fiscal efforts to alleviate the turbulence from the COVID-19 crisis in the world and in our country
}

\author{
Marija Gogova Samonikov ${ }^{1}$, Elena Veselinova ${ }^{2}$
}

UDC $338.23: 336.74]: 616.98: 578.834(100)$ 336.02]:616.98:578.834(100)

${ }^{1}$ Goce Delcev University, Faculty of Economics, Krste Misirkov St., 10-A, Republic of Macedonia, e-mail:marija.gogova@ugd.edu.mk

${ }^{2}$ Goce Delcev University, Faculty of Economics, Krste Misirkov St., 10-A, Republic of Macedonia, e-mail: elena.veselinova@ugd.edu.mk

Data says that nearly 128 million people have been infected with COVID-19 and more than 2.5 million people have died worldwide. This has been further compounded by an economic crisis caused by the disease's disruption to the world economy, resulting in millions of people losing their livelihoods, exacerbating global poverty and inequality.

The International Monetary Fund (IMF) estimates that the world economy, as measured by real gross domestic product (GDP), shrank by as much as $3.5 \%$ in 2020 . The MSCI All Country World Index (ACWI), which tracks large- and mid-cap companies in 50 developed and emerging countries around the world, fell into a bear market during March 2020, and didn't pass its pre-COVID-19 high until late August.

In response to this crisis, governments and central banks worldwide have enacted sweeping and sizable stimulus measures to counteract the disruption caused by the coronavirus and provide relief to those suffering from the pandemic.

Did these measures work? What is the right way out of the crisis? How long will this turbulence last? How long will the consequences last? Some of these questions are subject to variable answers, and some of these questions have yet to be answered. The purpose of this paper is to compare the measures implemented by countries and identify the best way to manage them to achieve faster economic recovery. Methods of analysis, comparisons and statistical calculations were used to show the real picture of the current situation.

Keywords

COVID -19, Managing, Monetary and fiscal policy.

\section{Introduction}

In response to the 2020 crisis caused by the SARS-CoV-2 virus pandemic, governments and central banks around the world have been forced to take huge and significant stimulus measures to counter the disruption that has occurred in all economic sectors, somewhere very, somewhere even more so, with the exception of the pharmaceutical industry. 
Representatives of many different government structures, from underdeveloped to developed countries, said that economies would be on the road to recovery only by using and comparing combined efforts for stimulus and assistance from central banks on the one hand and government measures and ministries on the other.

Many statesmen have compared the battle with this health problem with the situation in and after the Second World War, by being able to fight for the health of the global economy in addition to the battles for saving people's lives. The paper analyses several leading economies that have had significant medical challenges starting in the East, such as China, Russia, then the European Union and its members Germany, France, Italy, then the United Kingdom, Canada, and finally our economy and its fit into the situation. The analysis seeks to answer for managing of central bank-managed monetary policy and central government-led fiscal policy.

\section{Monetary and fiscal policies of world economies during the Covid pandemic}

We have already mentioned that the paper will make a comparison in the management of monetary and fiscal policies in the period from 2020 and this point is dedicated to that analysis. The analysis covers the most frequently commented countries from this crisis starting from the east to the west.

\subsection{China}

Whatever the truth, according to an investigation led by the World Health Organization (WHO), we know that markets in China, including the Juanhan market in Wuhan, played a key role in the onset of the pandemic. Wuhan was the place that alerted about the first spread of some kind of infection on a large scale at the end of 2019, ie the beginning of 2020. China, one of the most disciplined economies, has responded to the crisis with measures earlier than most countries. The Chinese experience in this whole situation has been a model for many countries in the world in dealing with the crisis both medically and economically.

Chinese monetary policy

According to a March 2021 Bloomberg report, China's central bank, the People's Bank of China (PBOC), plans to focus on mitigating any systemic financial risks. "The priority of the work is to build a conceptual system for preventing and controlling financial risk," said Chen Yulu, deputy governor. "We will further require shareholders, various creditors and local governments to carry out their responsibilities and work with financial regulatory bodies to maintain the bottom line to avoid systemic financial risks." A special alarm was sought in establishing the debt-to-GDP ratio and reducing the level of debt, especially at the level of local self-government.

In particular, China's monetary policy is implemented by injecting liquidity through redemption contracts as "reverse repo operations", although most other central banks call them "repo operations". The PBOC has cut a number of interest rates since the beginning of the crisis. Reduced primary one-year and five-year rates twice, once on 16 February 2020 and then again on 19 April 2020. This reduced the one-year rate from $4.15 \%$ to $3.85 \%$ and the fiveyear rate from $4.80 \%$ to $4.65 \%$. It also reduced its one-year medium-term loan (the rate at which it lends to banks) twice, once on 16 February 2020 and again on 15 April 2020. This contributed to the interest rate on the borrowing loan falling from $3.25 \%$ to $2.95 \%$, which is the lowest level since its introduction in 2014. On April 10, it reduced interest rates on loans by $0.30 \%$. PBOC reduced the seven-day repo rate on March 29, 2020 from $2.40 \%$ to $2.2 \%$. On June 17,2020 , it reduced its 14 -day repo rate from $2.55 \%$ to $2,35 \%$. 
According to the IMF, through repo operations and medium-term loans, the central bank injected about $\$ 650$ billion in liquidity into the economy as of June 11, 2020, and also expanded its \$254 billion lending and re-discounting capacity from June 11, 2020 in order to increase lending, especially for micro, small and medium-sized enterprises and the agricultural sector.

The PBOC has reduced bank reserve requirements as well as the interest rate paid on excess reserves.

\section{China's fiscal policy}

China was the only major economy to expand last year, with a sustained growth rate that is interdependent and with a wider global economic recovery.

After a year of major stimulus measures and subsidies to boost the economy and boost consumption, the Chinese government's statements show that we can expect a phase of "belt tightening" and a reversal of debt-driven growth.

As early as mid-March 2020, many local governments in China began issuing prepaid vouchers to increase consumer spending, but the amounts are reportedly relatively small. The Chinese government has asked banks to extend the terms of business loans and for commercial owners to cut rents. Regional and local governments are also increasing subsidies for certain car purchases and increasing the limit on the number of cars that can be owned. Banks have been asked to withdraw from mortgages. On May 22, Chinese Premier Li Keqiang said banks could allow small businesses to pay only interest on loans until the end of March 2021.

On May 22, 2020, the Chinese government unveiled a $\$ 506$ billion stimulus package that also included funding for local governments to stem the spread of COVID19 and cut business taxes. This was accompanied by the issuance of special government bonds by Beijing for the first time since 2007, along with an increase in the limit on special bonds that local governments can issue.

As of November 5, 2020, according to the IMF, $\$ 732$ billion in discretionary fiscal measures are estimated, with another $\$ 198$ billion in "out-of-budget support" such as tariff and fee cuts and small and medium-sized business loan guarantee. Measures are announced with total funding to fight the virus and include: Increase the cost of epidemic prevention; Production of medical equipment; Transfer of unemployment benefits; Tax relief on social security.

In general, the Chinese government is following a "cautious approach to withdrawing support for fiscal policy, as they seek to ensure a sustainable recovery of the economy from the coronavirus shock," according to Fitch. Analysts estimate that the country's consolidated fiscal deficit will be $7.5 \%$ of GDP in 2021 , compared to $9 \%$ last year. Fitch Ratings also predicts that government debt-to-GDP ratio will increase to about $57 \%$ by the end of the year.

\subsection{Russia}

The Russian economy has oil and gas as a weak link, which means that the sharp drop in oil demand due to quarantine and as a result of the Saudi-Russian war on oil prices was particularly significant for the Russian economy.

\section{Russia's monetary policy}

On April 24, 2020, the Russian Central Bank, the Bank of Russia, reduced the reference interest rate by $0.5 \%$ to $5.5 \%$. Following the stable maintenance of the key interest rate in May, the Bank reduced it to $4.5 \%$ in June and $4.25 \%$ in July. On March 27, the Bank of Russia disbursed a $\$ 2$ billion SME loan to help banks lend to SMEs so that SMEs could pay 
their employees during the crisis. On April 3, this loan program allowed banks above a certain credit rating to receive loans without collateral. The interest rate on this loan was reduced from $4 \%$ to $3.5 \%$ on April 24. The bank set aside another $\$ 0.7$ billion for emergency SME lending on May 15, 2020, and cut the rate to $2.5 \%$ in June and then to $2.25 \%$ in July. On March 10, the Bank of Russia implemented regulatory changes to increase lending, including allowing banks to have a lower capital buffer. On April 3, additional reduced capital requirements followed. On April 10, 2020, banks were given the opportunity not to assess the creditworthiness of loans in sectors harmful to the pandemic as a balance sheet quality, as well as to allow non-governmental pension funds not to reassess the value of assets acquired before March 17.

\section{Russia's fiscal policy}

Russia has announced it is creating a $\$ 4$ billion fund to help its economy during the COVID19 crisis on March 20, 2020. On April 7, President Putin announced that families with children would receive monthly payments of $\$ 67$ per family by June 2020 . On April 15, the Russian government announced a second stimulus package that includes: \$160 a month for SMEs per employee in April and May, provided they retain $90 \%$ of their workforce; $\$ 2.6$ billion for regional governments; $\$ 300$ million for airlines. On June 2, 2020, Russia announced a third round of stimulus spending estimated at $\$ 66.4$ billion. The plan includes business tax breaks, financing already announced extensions of social assistance payments, government guarantees for SME loans, fiscal transfers to regional governments and direct infrastructure costs. However, it is not clear how much of this plan is new spending and what are the existing expenditures that have just been reallocated from other parts of the budget or imposed to be spent earlier.

\subsection{European Union}

Following the slowdown in COVID-19 over the summer, countries across Europe saw an increase in new cases in the autumn and responded with new restrictions and closures of businesses, including Germany, France, Austria, Spain, Italy and others. The renewed restrictions in turn sparked widespread protests over the economic devastation already imposed by previous blockades and increased demands for further incentives and release measures.

\section{EU Monetary Policy (European Central Bank)}

Unlike the Federal Reserve, the European Central Bank did not have much room to cut interest rates. Its deposit interest rate is negative and its refinancing rate is 0 . This means it has had to rely on other monetary policy tools to respond to the current pandemic. While its reference interest rates remained the same, on March 12, 2020, it lowered interest rates and eased lending conditions for Target Long-Term Refinancing Operations (TLTRO III), a longterm bank lending program to keep liquidity stable. This was followed by the second reduction of the TLTRO III interest rate on April 30, 2020. On April 30, 2020, it announced a new series of term refinancing operations called "Long-Term Pandemic Refinancing Operations" (PELTRO) to provide additional loan liquidity. Throughout the spring and summer of 2020, the ECB activated or created currency exchanges with the central banks of Denmark, Croatia, Bulgaria and Romania. All of these are European countries that do not use the euro, and exchanges help to ensure that there are enough euros available in these countries for financing in euro denomination. On 25 June 2020, the ECB created a repository facility of the Eurosystem for Central Banks (EUREP) providing euro-denominated liquidity to 
central banks outside the euro area, in addition to what is provided for in the aforementioned exchanges. The ECB has significantly increased its bond-buying program. As of March 12, 2020, it announced an additional $\$ 128$ billion in bond purchases during 2020 . Then, on March 19, 2020, it announced a fundraising program called the Pandemic Emergency Procurement Program (PEPP), which will buy about $\$ 800$ billion in bonds and commercial paper during 2020. One notable feature is that Greek government bonds will qualify for purchase as part of this program. These bonds are normally excluded from buying bonds due to the country's credit rating. On June 4, 2020, the ECB announced that the PPP would expand by $\$ 680$ billion to a total of $\$ 1.5$ trillion and that the program would also be extended at least until the end of June 2021. The ECB said it would "conduct net procurement of funds under the PPP until it assesses that the coronavirus crisis phase is over." The ECB has also taken steps to increase liquidity. On March 12, 2020, this temporarily reduced the level of capital that banks need to have to enable them to increase lending. On April 7, 2020, it expanded what could be used as collateral for the ECB refinancing operations. The central bank says the measures are temporary and will be "overestimated before the end of 2020". On April 22, it allowed the assets whose credit rating was downgraded after April 7 to be used as collateral for ECB refinancing operations until September 2021. On December 10, 2020, the ECB announced another stimulus package.

\section{EU fiscal policy}

On 27 May 2020, the European Union presented its first proposal for a fiscal stimulus, financed by bonds issued by the EU itself, instead of by individual governments of its member states. This $\$ 860$ billion package is called the "next generation EU". Following the negotiations, the final package includes $\$ 450$ billion in grants and $\$ 410$ billion in loans. The package was originally approved on July 21,2020 , but was reviewed by the vetoes of Poland and Hungary. The package was finally adopted on December 9, 2020.

\subsection{Germany}

\section{Germany's fiscal policy}

As a eurozone country, Germany's monetary policy is pursued by the European Central Bank. The only German specific relief items adopted by the government are related to fiscal policy. To this end, Germany has implemented a wide range of aggressive fiscal stimulus and easing measures. Their efforts are by far the largest of all the countries in Europe in total size and as a percentage of the country's total GDP. By far the biggest relief measure was their Economic Stabilization Fund, released on March 23, 2020. The $\$ 650$ billion fund offers \$ 432 billion in loan guarantees, \$108 billion in shareholding in combat companies and \$ 108 billion in German Development Bank refinancing business loans. This was accompanied by an expansion of the types of loans that the development bank could offer. Also on March 23, Germany adopted an additional \$ 168 billion budget, suspending existing government debt rules to help finance additional KOVID-19-related costs, including the following: The \$ 54 billion emergency liquidity program dollars for small businesses, the self-employed, freelancers and farmers. Those categories of people and companies can apply to receive up to $\$ 16,200$ to cover operating costs; Increased PPP spending, vaccine research and other public health measures; Extended childcare benefits for low-income parents and easier access to social assistance for the self-employed; Extended funding for sharing payments (Job sharing is where companies reduce working hours as an alternative to layoffs. Employees are then partially or fully compensated by the government). In August, the government extended these wage subsidies until the end of 2021. On June 3, 2020, the German government announced another $\$ 146$ billion stimulus package. Among other things, 
the package includes the following: Value Added Tax (VAT). The normal VAT rate will be reduced from $19 \%$ to $16 \%$ for all goods. The new rate took effect on July 1 and lasts until December 31, 2020. The reduced rate of value added tax, which refers to the most important things such as food, was reduced from $7 \%$ to $5 \%$. These tax cuts are estimated to cost around US \$22.5. \$ 4.3 billion to give parents a one-time cash payment of $\$ 337$ per child. \$ 6 billion to support German social security programs. $\$ 12.4$ billion in renewable energy tariff reductions for 2021 and 2022. $\$ 9$ billion in business tax cuts. $\$ 28.1$ billion in aid for small and medium-sized businesses to make up for the losses associated with the virus. \$2.1 billion in aid to cultural and non-profit organizations. \$11.2 billion in local government aid. \$ 4.5 billion in school aid. On March 19, 2020, the German Ministry of Finance announced that taxpayers who can prove that they are directly and significantly affected by the KOVID-19 pandemic can apply for a tax deferral or reduction that they owe until December 31, 2020. In 2020 , the value added tax for restaurants and catering services has been reduced from $19 \%$ to $7 \%$.

\subsection{France}

France's fiscal policy

As a eurozone country, France's monetary policy is pursued by the European Central Bank. The only facilitation aspects specific to France that the government has adopted are fiscal policy. France's biggest relief measure COVID-19 is a package of loan guarantees to help businesses survive the crisis. The current package includes $\$ 323$ billion in loan guarantees. On April 17, 2020, all business tax filings for May were postponed to June 30, and businesses can request a tax filing in May. Large companies will receive a deferral only if they do not issue a dividend or redemption by the end of 2020.119 The calendar for filing taxes for individuals is withdrawn in 10 days. On March 17, French Finance Minister Bruno Le Maire announced a $\$ 49$ billion aid package, which was expanded to $\$ 119$ billion on April 15. The aid package includes the following: $\$ 8.7$ billion in increased spending on health supplies and aid the health system; $\$ 26$ billion in increased funding to support wage-sharing; $\$ 7.6$ billion in direct payments to the self-employed and many small businesses; Deferment of rent and utilities for small and medium enterprises; Extension of unemployment benefits; Business loan savings funds. On June 10, 2020, the French government increased the size of its stimulus package to an additional $\$ 154.6$ billion. The additional fund will be used to support wages, tax delays and support for sectors that have been particularly severely affected by the pandemic, such as tourism and the airspace. On September 3, 2020, France announced another $\$ 118.4$ billion in stimulus. The incentive package will be spent over two years and focuses on supporting economic growth. It includes $\$ 41.5$ billion for businesses to "make the French economy more competitive" and $\$ 35.5$ billion for the transition of the French economy away from fossil fuels. The remaining money will be spent on job support and training programs to promote consumer confidence and create 160,000 jobs. On October 29, 2020, French Finance Minister Bruno Le Maire announced another \$ 23.7 billion in small business assistance, wage subsidies for deceived workers, and extended funding for direct and guaranteed business loans until June 2021.

\subsection{Italy}

Italy's fiscal policy 
As a eurozone country, Italy's monetary policy is pursued by the European Central Bank. The only Italian-specific relief items brought by the government are related to fiscal policy. Italy has launched four separate stimulus packages.

The first package of incentives and relief was announced on March 16, 2020, the Italian government announced its first package of incentives, the law "Cura Italia" (care for Italy). It contains approximately $\$ 27$ billion focused on four major "pillars". The first is $\$ 3.5$ billion to strengthen Italy's healthcare system and purchase personal protective equipment. The second is $\$ 11.2$ billion to help protect workers. These include boosting unemployment benefits, a US \$ 650 allowance for the self-employed and seasonal workers in March, extended parental leave or US \$650 childcare allowance, and extending paid leave for those caring for disabled relatives. This pillar also includes funds for hiring 1,000 additional doctors and paying for overtime work of the police. Families can apply for a mortgage termination if a pandemic threatens their livelihood. The third plan includes $\$ 5.5$ billion to increase the liquidity of businesses and households. This includes, but is not limited to: SME Loan Repayment Moratorium (SME); Increase the guaranteed SME fund that helps SMEs get credit; A \$ 500 million loan guarantee for the Italian state-owned investment bank for large businesses to obtain loans; The fourth pillar includes $\$ 1.7$ billion in tax suspensions and tax incentives. All businesses, the self-employed, as well as individual taxpayers working in sectors affected by the pandemic, had their taxes and social security contributions suspended in March 2020. Withholding tax on wages paid to the self-employed with an income of less than \$433,500 per year was suspended for both March and April 2020. Audits, litigation and forced tax collection are suspended until June 2020. All costs for sanitation, worker protection or virus retention are eligible for a $50 \%$ tax. Shops and small businesses closed due to the state of emergency will receive a tax credit equal to $60 \%$ of the rent in March 2020. Workers still working and earning less than $\$ 43,400$ a year will receive a $\$ 108$ bonus; The bill also includes $\$ 4.9$ billion to support "central and local public administrations, including municipalities." The second stimulus package was released on April 6 and was significantly larger than the first. The Liquidity Repayment Act will offer $\$ 432$ billion in loan guarantees from the government and its state-owned investment bank and export bank. A third package of $\$ 59.6$ billion was approved on May 13, 2020. Among other things, it includes the following: $\$ 28.8$ billion in assistance to employees and the selfemployed. This includes additional funding to support wages and payments of $\$ 450$ to $\$ 900$ per month for those without income but who are not otherwise covered by welfare programs; A measure that allows undocumented migrants to obtain temporary work documents to work as agricultural workers or caregivers; $\$ 4.5$ billion in regional tax cuts; Loan guarantees of up to $\$ 16.9$ billion for bonds to support banks to support financial stability. On October 26, 2020 , Italy adopted the fourth stimulus package worth $\$ 6.4$ billion. Includes $\$ 2.9$ billion in one-time payments of business subsidies, subsidies and tax cuts for rent and housing, and an 18-week extension of wage support under the previous incentive plan.

\subsection{Great Britain}

The UK differs from other major European economies in two main ways. The first is that it has its own central bank, unlike Germany, France and Italy. The monetary policy of those countries is led by the European Central Bank. The other is that the UK is undergoing a massive change in its laws and trade relations due to Brexit and was in the process of negotiating its trade relations with the EU when the pandemic started. Like other European countries, the UK has once again tightened its household and economic constraints amid rising COVID-19 cases in the autumn, raising the urgency for further economic stimulus. 
The Bank of England has taken a number of steps to try to mitigate the pandemic and the resulting economic crisis, using all its tools and lowering record-breaking rates. The Bank of England (BoE) cut its benchmark interest rate twice. On March 11, 2020, the bank reduced it from $0.75 \%$ to $0.25 \%$. And on March 19,2020 , it was reduced from $0.25 \%$ to $0.1 \%$. On March 24, the BoE activated its Contingent Repo Facility (CTFR), an additional three-month repo operation in addition to existing ones. On March 19, 2020, the BoE announced that it would restart QE with $\$ 246$ billion in government and non-financial corporate bonds. On June 5, 2020, the BOE expanded what types of bonds it could purchase in its QE program. The BOE expanded its bond purchases to another $\$ 124$ billion on June 18, 2020. On November 5, 2020, the Bank expanded its target for the purchase of government bonds for an additional \$ 197 billion. The BOE has launched a number of additional lending and purchase programs to extend credit during the crisis. On March 11, 2020, the BoE announced the Financing Scheme, which offers additional incentives for small and mediumsized enterprises (TFSME). This scheme offers BOE loans to banks that use bank loans to businesses as collateral for a central bank. Banks will get more money if they lend to small and medium-sized businesses. TFSME started operations on April 15, 2020. On March 17, the BoE launched the Corporate Finance Facility (CCFF), which will buy commercial paper for at least 12 months. There are no procurement restrictions.105 The program was updated on May 19, 2020, allowing businesses to repay their debt early. The new rules say that all business entities wishing to issue a commercial paper with a maturity of 19 May 2021 should draw up a plan showing how to reduce dividends, ransoms and executive payments while the debt is still outstanding. . As for regulatory changes, on March 11, 2020, the BoE allowed banks to use a reserve they call a "countercyclical capital buffer". The buffer is money kept in reserve to increase banks' resilience to global financial shocks, allowing nearly $\$ 390$ billion in new loans. It also canceled the banking stress test in 2020. However, on July 28, 2020, the BoE Regulatory Authority also reiterated its expectation that banks would suspend dividends, redemptions, and senior staff cash bonuses by the end of 2020 to assess financial distribution plans. companies and over 2020. On April 9, 2020, the BoE announced that it would lend directly to the government if bond markets were not sufficient to meet fiscal requirements during the COVID-19 crisis.

\section{UK fiscal policy}

The UK's fiscal policy came in six packages. The first, released on March 11, 2020, set aside nearly $\$ 37$ billion in fiscal stimulus and relief in the UK budget. Among other things, it includes activities with taxes, small businesses, wages, the self-employed and the unemployed. The second wave, introduced on March 17, 2020, includes \$ 379 billion in business loans and loan guarantees. These loan schemes are divided into the Coronavirus Business Credit Scheme (CBILS) for Small and Medium-sized Businesses and the Coronavirus Business Credit Scheme (CLBILS) for Larger Businesses. The package also included $\$ 23$ billion in tax cuts for businesses and a grant to fund businesses most affected by the virus, such as retail and hotel businesses. The third package, announced on March 20,2020 , includes a program to provide grants to companies that cover up to $80 \%$ of workers' wages, if companies keep them on wages, instead of firing them, tax credits, housing. The fourth package, announced on March 26, 2020, provides cash grants of up to $\$$ 3,080 to the self-employed with earnings of $\$ 61,600$ per year. Payments will continue monthly for at least three months. A fifth package of incentives and relief worth $\$ 37.6$ billion was announced on July 8, 2020. Among other things, it contains activities with employment programs for persons under 25, bonuses, training, education, reduction of sales tax from $20 \%$ to $5 \%$, infrastructure, reduction of transaction taxes. The sixth package, released on September 24, 2020, includes wage subsidies of up to $\$ 907$ per month for workers facing reduced hours, extension of small business self-employment income support grants until April 2021, extension of loans below previous packages until the end of November 2020 and 
the continuation of the 15\% VAT reduction for the catering and tourism businesses until March 2021. The UK also adopted several smaller measures during the spring of 2020. On March 23, it announced a measure to ensure that no commercial tenant could be expelled if they missed payment by June 30, 2020.

\subsection{Canada}

Canada, the world's tenth largest economy, has made several major moves to combat KOVID-19 economic stress. Its central bank has launched its first QE program to date, while its government has offered a large $\$ 75$ billion bailout package, which includes expanded unemployment insurance and wage subsidies.

\section{Monetary policy of Canada}

The Bank of Canada, Bank of Canada (BOC), has cut its benchmark interest rate three times since the beginning of March 2020. Specifically, these reductions, each of which reduced the rate by $0.5 \%$, occurred on March 4, March 13 and March 27, 2020, bringing the rate from $1.75 \%$ to $0.25 \%$. On July 15,2020 , the Bank announced that it reiterated its intention to maintain current interest rates and quantitative easing policies until it achieves its $2.0 \%$ inflation target. On March 12, 2020, the BOC added a 6-month and 12-month repo operation, in addition to existing 1-month and 3-month repo contracts. On March 18, 2020, the BOC expanded the types of securities that could be used as collateral for repo operations. Then, on March 20, it announced that it was increasing the frequency of its repo operations to at least twice a week, from once a week. The BOC announced that it was activating its Renault Profitable Contingent facility on April 3, 2020, which offers additional one-month repo contracts and is being activated to "counter severe market liquidity stresses". A bank lending program called "Remaining Permanent Liquidity" has been expanded. Lends to a wider range of banks and accepts a wider range of collateral than repo programs. It has also launched a program, originally announced in 2019, called the Permanent Liquidity Term, which provides loans to an even wider range of banks and accepts an even wider range of collateral than the Residual Permanent Liquidity. In June, based on the improvement of economic data, the Bank started to slow down the pace of repo operations and banking activities. BOC announces its first QE programs. During March 2020, the BOC announced plans to buy $\$ 2.1$ billion worth of government bonds each week, as long as "the economic recovery is underway." , money market securities from provincial governments and commercial paper. In April, it announced a provincial-government bond-buying program that would hold up to $\$ 35.5$ billion in bonds and a $\$ 7.1$ billion corporate bond-buying program, both of which will begin in early May, 2020. On March 18, the BOC asked retailers to continue accepting cash to ensure there were no disruptions to the cash supply. In addition, the Office of the Supervisor of Financial Institutions (OSFI), a Canadian financial regulator, has reduced its bank reserve requirements to allow banks to lend an additional $\$ 214$ billion.

\section{Canada Fiscal Policy}

Canada has launched an escalating series of measures. The first, released on March 11, 2020 , contained $\$ 781$ million to support research, assist provincial governments, and invest in such public health measures as mask purchases. On March 13, the government announced a $\$ 7.1$ billion business loan program. The assistance was aimed at: Sending a monthly payment of 1420 USD every four weeks to 28 weeks to people who lost their income due to KOVID-19; Increase benefits for Canadian children by 2020 by $\$ 213$ per child; Onetime payment of 284 USD to low-income people; Continuation of income tax filing in both the 
United States and income tax until June 1, 2020 and tax payment until September 1, 2020; Enabling lenders to offer deferred payment for up to six months for government-secured mortgages; The program, which runs from March 15 to June 6, 2020, covers $75 \%$ of wages up to US \$ 600 per week for businesses that have suffered a $15 \%$ or more revenue decline; $10 \%$ salary subsidy for small businesses that do not meet the requirements for the above subsidy; $75 \%$ rental relief for small businesses that had to close or lose $70 \%$ of their income from KOVID-19; Deferred payment of sales tax and import duties until June 30, 2020.

In addition, the Canadian Mortgage and Housing Corporation (CMHC), a government-owned housing corporation, announced on March 16, 2020 that it would purchase secured mortgages of up to $\$ 35.6$ billion. This amount was increased to 106 billion dollars.

\section{Monetary and fiscal policies of Macedonia during the Covid pandemic}

The Macedonian economy before the outbreak of the epidemic was not characterized by significant growth and stability, and this situation only further affected the borrowing and aspects that contribute to more difficult to achieve capital goals, which for the Macedonian economy continuously seem to be an unfulfilled dream.

\section{Macedonian monetary policy}

On March 9, 2021, a regular session of the Operational Monetary Policy Committee of the National Bank was held, at which the developments in the international and domestic financial markets and the indicators of the domestic economy in the context of the monetary policy stance were reviewed.

At that session it was decided to reduce the key interest rate by an additional 0.25 percentage points, to the level of $1.25 \%$. The decision for further monetary easing is made in conditions of stable movements in the foreign exchange market and moderate inflation dynamics, while there is still uncertainty about the health crisis and the impact on the recovery path of the economy. In support of the decision is the more pronounced adaptive character of the ECB in order to maintain favorable financial conditions in the long run. The further easing of monetary policy is to further ease financial conditions and further support the domestic economy, given the ongoing development of the pandemic, which is still ongoing. It was also decided to realize an offer of CB bills in unchanged amount of 10 billion denars.

Further easing of monetary policy is expected to reduce the cost of financing through bank loans and further lending to the private sector, in order to mitigate the effects of the pandemic on the domestic economy.

According to the latest available macroeconomic indicators for economic activity, in the last quarter of 2020 the decline in gross domestic product slowed down, in line with expectations, and the economic decline for the entire 2020 is mainly within the latest projections. Namely, the gross domestic product in the last quarter of 2020 dropped by $0.7 \%$ on annual basis, after the decline of $3.3 \%$ in the previous quarter. Thus, the real decline of the economy in 2020 is $4.5 \%$, which is in line with the projections of the National Bank for a decline of $4.9 \%$. 
The available high frequency data for the first quarter of 2021 are limited and for now it is difficult to draw clear signals for economic activity in this period.

Regarding the inflation movements, in the first two months of 2021 the price changes are moderate and are in line with the expectations according to the latest projection of the National Bank. In terms of revisions, mainly upwards in the external input assumptions, the uncertainty from the movement of world prices of primary products in the next period and their impact on domestic prices is still emphasized.

Foreign exchange reserves remain at an appropriate level and are maintained in the safe zone. The latest data from the external sector for January 2021 indicate a slightly lower trade deficit than expected for the first quarter of the year, while the latest data on foreign exchange operations do not deviate significantly from expectations in line with the October projection. The balance of payments performance for the whole of 2020 indicates a moderately lower current account deficit and moderately higher financial inflows, compared to the expectations with the October projection.

Within the monetary sector, according to the initial data for February 2021, the annual growth of total deposits and loans continues, with the growth of total loans being more moderate than projected for the first quarter of 2021 according to the October projection.

In the period between the two sessions of the Committee, the liquid assets of the banking system were maintained at a solid level, due to which the need of the banks to trade with short-term Denar liquid assets on the money markets is still low. Market movements, accompanied by the banks' solid foreign exchange liquidity in February, contributed to a further reduction in the amount of foreign exchange interventions by the National Bank for banks, which was the lowest since the beginning of the crisis.

In February, as the coronavirus vaccination process took place around the world, investors in international financial markets had more positive expectations for the recovery of the global economy. In such conditions, as well as due to the prospect of additional fiscal stimulus in the United States, government bond prices in the United States fell sharply, which contributed to the reduction of government bond prices in the euro area. The euro / US dollar also fell, largely due to the prospect of a faster recovery of the US economy and the perception that the Fed will begin the process of tightening monetary conditions sooner.

\section{Macedonian fiscal policy}

The government, like other international government structures, has consistently kept pace with global recommendations for measures to address current developments, although this has sometimes been more confusing than clear. The measures that this institution has taken so far are divided into six packages. Intended for:

Financial support for the citizens - for higher consumption and for development of domestic economic activities; (Payment cards for the citizens, Voucher for home tourism "You are at home" of 6,000 denars and home payment card "I buy at home" of 3,000 denars to buy Macedonian products and services, Financial support for young people of 6,000 denars and home payment card " I buy at home "from 3,000 denars to buy Macedonian products and services, Vouchers up to 30,000 denars for co-financing trainings, trainings and courses for 
IT and digital skills for young people aged 16 to 29 , Weekend without VAT, Thanks for the most exposed health workers).

Direct support to the Macedonian economy - for innovation and development, for preservation of existing and new jobs; (Interest-free loans to companies through the Development Bank of Northern Macedonia, worth EUR 31 million - support for women, youth and digitalization in business, State guarantee for commercial loans and customs debt security, New EUR 25 million for the private sector - for new markets, competitiveness and modernization, Digital platform for new markets for textile and shoe companies, Support for development of domestic start-up products and services through FITR, Instrument for technological development for quick adaptation, Co-financing of events and conferences with $50 \%$ financial support from the state, up to 30,000 denars, Support for payment of salaries, Interest-free credit lines KOVID 1 and KOVID 2 from the Development Bank of RSM, Fifty million euros cheap loans from the Development Bank of RSM placed through commercial banks for protection of companies' liquidity, of the grace period for interest-free loans from KOVID-1, New EUR 100 million favorable loans from Development Bank of the Republic of Northern Macedonia., Refund of the tourist tax for 2019, Grants for travel agencies from 3,000 to 7,000 euros, Grants for restaurants for weddings, Extension of licenses to operate discos, nightclubs and companies from the transport community, Grants for playgrounds for children, Additional postponement of repayment of loans for companies, until the end of the year., Deletion of the condition for collecting points from Continuing Professional Development $(\mathrm{PI})$ for renewal of license for accountants, Subsidies for private institutions for children-kindergartens, Grants for educational centers for children, Grants for centers for foreign languages, Financial assistance for night clubs, Financial assistance to $\mathrm{MZ}$ Transport, Financial assistance for 58 licensed carriers, Financial assistance for payment of salaries for GTC AD Skopje, Financial support for AD Vodsto , Financial assistance for carriers - MAKEKSPRESS PREVOZ DOO Skopje, Financial assistance for carriers - DPPU Sloboda prevoz Sk General, Financial support for salaries for employees, Loans with 0\% interest for the most affected sectors (tourism, crafts, catering, transport, event industry, private health facilities, etc.) through the Development Bank, Financial support for broadcasters, Exemption from compensation for MUKS for broadcasters in 2021, Financial support for registered craftsmen, Financial support for international transporters for payment of wages for March and April, From 3,000 to 10,000 euros for about 200 registered companies that transport passengers and had a more than $50 \%$ decline in Revenues, Credit guarantee scheme in the period April - October 2021 through the Development Bank ,, Extension of the grace period for payment of liabilities for borrowers of the credit line "Kovid $2 "$ at the Development Bank, Support of events of public interest for companies that organize events, production houses, national and local televisions and radios, Financial support for operating hotels outside the tourist centers, which did not use vouchers, Export Company Support Fund through Development Bank, Support for sports clubs 33\% of the amount they receive under the voucher system to be paid from the Budget at the beginning of the year, Abolition of customs rates for 71 products and raw materials by the end of 2021, Abolition and reduction of customs tariffs for 31 raw materials and meat for export companies by the end of 2021, Support for export companies Revision of the Customs Tariff and compliance with EU market rules and markets of WTO members, Facilitation conditions for 245 companies that have active contracts and new ones that will invest according to the Law on Financial Support of Investments, Co-financed assistance for micro, small and medium enterprises and private health institutions for technological development for accelerated economic growth in KOVID-19 period through FITR, Use of funds from unused block grants for the municipalities for capital investments, Financial support for 38 health workers left out of the third package of measures ,, Exemption from contractual obligations (payment of penalties) for contracts signed with LSGUs of companies affected by the crisis, Financial support for Roma entrepreneurs creation of "Matching Fund for Entrepreneurship for Roma", Digital transformation of businesses for faster post-quid revitalization for micro and small 
enterprises, Financial support for 6,000 caterers with about 17,000 employees, Financial support for private children's resorts, nightclubs, playgrounds, weddings, event industry, fitness centers, photographers and photographic studios, Financial support for corporate liquidity, Interest-free credit line for radio and television broadcasting media.

Support for farmers - new income from the fertile Macedonian land; Direct assistance for the unemployed, athletes, artists and tour guides; Tax breaks and debt relief.

In essence, the first two sets of economic measures have dampened the first blow of the economic crisis caused by the coronavirus. The main features of these package measures were their timeliness, their comprehensiveness and their precise sizing. The Republic is a welfare state and a society of solidarity, in which every citizen needs and receives support. In that sense, the third package of economic measures will enable the revival of the Macedonian economy through direct support of the citizens and the economy. This package of measures for a new, developing Macedonian economy will increase consumption and stimulate the protection, promotion and growth of the domestic economic supply. The third package of measures is intended for: Citizens: unemployed, socially vulnerable categories, young people (high school students, students and young people up to 29 years), low-income households, medical staff; For the economy: the sectors affected by the crisis, domestic companies (manufacturing, food and other facilities), export companies, services, agriculture and tourism. The main aspects include: Encouraging the private consumption of the citizens, which creates conditions for a better life; Protecting existing and creating new jobs, especially in the sectors in which digitalization will be implemented. Increased competitiveness of our companies at domestic, regional and global level; Intervention activation of domestic tourism; Promotion of new crops and support to farmers for even greater volume and quality of domestic production Development of economic activities with the introduction of IT and online activities and tools; Stimulating and increasing non-cash and online payments, as a tool to combat the shadow economy.

The fourth package of measures, called: The successful strategy for preventing the collapse of the health system and the economy and social security, created conditions for the fourth package of economic measures. The fourth package aims to ensure the sustainability of domestic economic activities and jobs, to recover certain activities, to ensure the stability of social transfers and to provide policies that will help implement a rapid exit strategy when the crisis is over so that we can continue with positive trends. of the new developing Macedonian economy. Therefore, the support for the citizens and the economy continues and no one will be left out. We have in mind all activities and companies. Our attention is fully focused on support for jobs, the unemployed, socially vulnerable categories such as retirees and citizens of other categories, single parents, etc. The fourth package of measures is a direct help for the economic and social security of our fellow citizens, as well as for encouraging private consumption as a stimulator of social growth.

The fifth package of measures for a stable and developing economy intended for citizens and companies, and for improving the liquidity of the economy. The fifth package contains a total of 29 measures, worth 9.7 billion denars or about 160 million euros.

The sixth package of anti-crisis economic measures worth 17.8 million euros is intended to support activities that were completely closed in order to prevent the spread of coronavirus during April 2021, as well as to improve the liquidity of companies investing during 2021 . . The sixth package of measures includes seven measures that target the most affected sectors of the corona crisis, and will support 10,000 companies, which employ about 60,000 citizens. 


\section{Conclusions}

After all, from the analyzes made in this paper, it can be concluded that the policies in the countries are very similar. Their steps seem to follow each other.

From the aspect of monetary management, the central banks are focused on reducing the primary and interest rates in general, on putting money into circulation. The case of the European Central Bank is special, where due to the limited maneuvers with low or nonexistent interest rates, the measures are also aimed at buying bonds.

In contrast, fiscal policies cover socially disadvantaged categories. Various steps from recommendations to commitments have been applied across different countries to create a favorable climate for both the amortization of health centers and the amortization of economic shocks.

In essence, the point of managing these measures and their potential evasion is yet to come to light. The recovery of the economies is still a challenge, especially due to inflationary pressures.

The conclusion would be that the countries applied measures, that the central governments and the central banks are coordinating everywhere because the situation is far from stable. In some countries the emphasis is more on monetary criteria, in others on fiscal and government activities.

In any case, there are measures. The most important is their timely and correct use.

\section{References}

1 Wall Street Journal. "China Becomes First Major Economy to Start Withdrawing Pandemic Stimulus Efforts," Accessed March 30, 2021.

2 Reuters. "China c.bank cuts 14-day reverse repo rate, injects net 40 bln yuan," Accessed June 18, 2020.

3 International Monetary Fund. "POLICY RESPONSES TO COVID-19." Accessed June 13, 2021. On March 13, the PBOC lowere

4 S\&P Global Market Intelligence. "China asks banks to up lending, relief to small business despite rising defaults," Accessed June 17, 2020.

5 Bank of Russia. "The Bank of Russia cuts the key rate by 100 bp to $4.50 \%$ p.a.," Accessed September 3, 2020.

6 The Moscow Times. "In 4th Coronavirus Address, Putin Calls for Stronger Business Support," Accessed May 13, 2020.

7 European Central Bank. "ECB announces new pandemic emergency longer-term refinancing operations," Accessed May 13, 2020.

8 Bruegel. "The fiscal response to the economic fallout from the coronavirus," Accessed May 13, 2020.

9 France24. "France boosts Covid-19 economic rescue package to $€ 110$ billion," Accessed May 13 , 2020.

10 Ministry of the Economy and Finance. "Protect health, support the economy, preserve employment levels and incomes," Accessed May 13, 2020.

11 Bank of England. "Monetary Policy Summary for the special Monetary Policy Committee meeting on 19 March 2020," Accessed March 19, 2020.

12 GOV.UK. "Chancellor announces additional support to protect businesses," Accessed May 13, 2020.

13 Bank of Canada."Bank of Canada lowers overnight rate target to $1 \frac{1 / 4}{4}$ percent," Accessed March 16, 2020.

14 Department of Finance Canada. "Canada outlines measures to support the economy and the financial sector," Accessed March 16, 2020. 
15 https://vlada.mk/

16 https://www.nbrm.mk/

17 https://finance.gov.mk/ 